\title{
Hubungan Pengetahuan dan Sikap Ibu Primipara yang Bekerja dengan Keberhasilan Pemberian ASI Eksklusif di Puskesmas Umbulharjo I Yogyakarta
}

\section{The Relationship of Knowledge and Attitude of Primipara Working Mothers with Successful Exclusive Breast-Feeding at Puskesmas Umbulharjo I Yogyakarta}

\author{
Yanti Susilawati ${ }^{1 *}$, Endar Timiyatun ${ }^{2}$, \\ 1. Jurusan Keperawatan, STIKes Surya Global Yogyakarta \\ 2. Jurusan Keperawatan, STIKes Surya Global Yogyakarta \\ *Email Korespondensi: yantisusilawati1233@gmail.com
}

\begin{abstract}
Abstrak
Latar belakang: Air Susu Ibu (ASI) merupakan makanan terbaik untuk bayi. ASI secara alami dan sempurna telah disesuaikan dengan kebutuhan bayi baru lahir. ASI mengandung jumlah nutrisi yang tepat dan memberikan nutrisi pada bayi. ASI juga mengandung antibodi penting yang diberikan dari ibu yang membantu untuk melindungi bayi terhadap sejumlah infeksi.

Tujuan: Untuk mengetahui hubungan pengetahuan dan sikap ibu tentang ASI eksklusif dengan keberhasilan pemberian ASI eksklusif pada ibu primipara yang bekerja di wilayah kerja Puskesmas Umbulharjo 1 Yogyakarta.

Metode: Jenis penelitian kuantitatif dengan menggunakan rancangan cross sectional. Sampel dalam penelitian ini sebanyak 32 responden dengan teknik sampling jenuh.

Hasil: Hasil menunjukkan bahwa mayoritas ibu memberikan ASI eksklusif yaitu 22 orang $(68,8 \%)$ dan minoritas ibu yang tidak ASI eksklusif yaitu 10 orang $(31,2 \%)$ yang berarti pengetahuan yang baik dan sikap baik ibu primipara yang bekerja akan cenderung memberikan ASI eksklusif. Hasil uji chi square $\mathrm{p}=0,000(\mathrm{p}>0,05)$ menunjukan bahwa ada hubungan sikap Ibu tentang ASI eksklusif dengan keberhasilan pemberian ASI eksklusif pada ibu primipara yang bekerja di wilayah kerja Puskesmas Umbulharjo I Yogyakarta.

Kesimpulan: Terdapat hubungan pengetahuan dan sikap ibu tentang ASI eksklusif dengan keberhasilan pemberian ASI eksklusif pada ibu primipara yang bekerja di wilayah kerja Puskesmas Umbulharjo 1 Yogyakarta. Penelitian ini dapat dijadikan pedoman bagi ibu primipara yang bekerja dalam meningkatkan pengetahuan dan sikap ibu tentang ASI eksklusi dengan keberhasilan pemberian ASI Eksklusi. Diharapkan penelitian selanjutnya dapat mengkaji faktor-faktor lain yang mempengaruhi keberhasilan pemberian ASI eksklusif.
\end{abstract}

Kata kunci: ASI Ekslusif; Pengetahuan; Primipara; Sikap

\begin{abstract}
Background: Mother's milk is the best food for a baby. Breast milk is naturally and perfectly adapted to the needs of newborns. Breast milk contains the right amount of nutrition and feeds the baby. Breast milk also contains important antibodies from mothers that help to protect a baby against a number of infections.

Objective: To know the relation of your knowledge and stance on exclusive breast milk with the success of exclusive breast-feeding working mothers primipara who work in the region of Puskesmas Umbulharjo I Yogyakarta

Method: The kind of quantitative research that USES sectional designs. The sample in this study is 32 respondents with a saturated sampling technique

Result: The results showed that most of the mothers gave exclusive breastfeeding, namely 22 people (68.8\%) and a small proportion of mothers who did not give exclusive breastfeeding, namely 10
\end{abstract}


people (31.2\%) which means good knowledge and good attitudes of working primiparous mothers. will tend to breastfeed. exclusive. The results of the chi square test $p=0.000(p>0.05)$ showed that there was a relationship between the mother's attitude about exclusive breastfeeding and the success of exclusive breastfeeding for primiparous mothers who worked in the working area of the Umbulharjo I Health Center Yogyakarta

Conclusion: There is a correlation between mother's exclusive breast milk and the successful exclusive breast-feeding of working mothers primipara who work in the region of Umbulharjo I Yogyakarta. This study can be used as a guideline for primiparous mothers who work in increasing knowledge and attitudes about exclusive breastfeeding. It is hoped that further research can exanibe other factors that influence the success of exclusive breastfeeding.

Keywords: Attitude; Exclusive Breast-Feeding; Knowledge; Primiparous

\section{PENDAHULUAN}

Air Susu Ibu (ASI) merupakan makanan terbaik untuk bayi. ASI secara alami dan sempurna telah disesuaikan dengan kebutuhan bayi baru lahir. ASI mengandung jumlah nutrisi yang tepat dan memberikan nutrisi pada bayi. ASI juga mengandung antibodi penting yang diberikan dari ibu yang membantu untuk melindungi bayi terhadap sejumlah infeksi(1).

World Health Organization (WHO) telah merekomendasikan standar emas pemberian makanan pada bayi yaitu menyusui bayi secara eksklusif sejak lahir sampai dengan umur 6 bulan, didahului dengan Inisiasi Menyusu Dini (IMD) segera setelah lahir, mulai umur 6 bulan diberikan Makanan Pendamping ASI (MP-ASI) dan diteruskan menyusu hingga anak berumur 2 tahun. Di Indonesia juga menerapkan peraturan terkait pentingnya ASI eksklusif yaitu dengan mengeluarkan Peraturan Pemerintah (PP) nomor 33/2012 tentang pemberian ASI eksklusif yang menyatakan kewajiban ibu untuk menyusui bayinya sejak lahir sampai bayi berusia 6 bulan(2).

Berdasarkan hasil Riskesdas 2018, proporsi pola pemberian ASI pada bayi umur 0-6 bulan di Indonesia sebanyak 37,3\% ASI ekslusif, 9,3\% ASI parsial, dan 3,3\% ASI predominan. Berdasarkan tempat tinggal, prosentase penduduk kurang dari 6 bulan yang pernah diberi ASI tahun 2017, sebanyak 26,4\% di daerah perkotaan dan 25,1\% di daerah perdesaan. Hal ini sejalan dengan hasil Riskesdas 2018, yaitu proporsi ASI eksklusif pada bayi usia 0-6 bulan lebih banyak di perkotaan 40,7\% dibandingkan Pedesaan 33,6\%. Provinsi dengan proporsi tertinggi pemberian ASI pada bayi umur 0-6 bulan tahun 2018 adalah Provinsi Kepulauan Bangka Belitung 56,7\%. Sedangkan provinsi dengan proporsi terendah yang pertama adalah Provinsi Nusa Tenggara Barat 20,3\%, yang kedua Nusa Tenggara Timur 21,3\% dan yang terendah ketiga adalah Daerah Istimewa Yogyakarta 23,3\%(3).

Menurut Dinas Kesehatan Daerah Istimewa Yogyakarta (2017), bahwa porsentase pemberian ASI eksklusif pada bayi umur 0-6 bulan tahun 2017 paling tinggi terjadi di Kabupaten Sleman 82,62\% dan urutan rendah pertama terjadi di Kota Yogyakarta 66,13\%, urutan terendah kedua kabupaten gunung Kidul 66,76\% dan urutan ketiga Kabupaten Bantul 74,27\% (Profil Kesehatan DIY, 2017). Menurut Dinas Kesehatan Kota Yogyakarta (2017), bahwa porsentase pemberian ASI eksklusif pada bayi umur 0-6 bulan tahun 2017 paling tinggi terjadi di Mantrijeron 80,41\% dan urutan terendah terjadi di Umbulharjo 1 35,38\%(2).

Menurut Baker (2009) dalam Profil Kesehatan DIY (2017) Air Susu Ibu (ASI) adalah salah satu faktor yang mempengaruhi status gizi bayi umur 0-6 bulan. Selain itu, pemberian ASI secara eksklusif menghindarkan bayi dari kematian yang disebabkan oleh penyakit anak, mempercepat penyembuhan selama sakit, dan membantu dalam proses kelahiran(2).

Beberapa manfaat pemberian ASI bagi bayi antaranya dapat memberikan kehidupan yang baik dalam pertumbuhan maupun perkembangan bayi. Bayi yang tidak diberikan ASI 
eksklusif akan lebih rentan untuk terkena penyakit kronis, seperti jantung, hipertensi, dan diabetes setelah ia dewasa serta dapat menderita kekurangan gizi dan mengalami obesitas(4).

Menurut Walyani (2015) dalam Yusrina (2016) pemberian ASI eksklusif selain bermanfaat bagi bayi juga bermanfaat bagi ibu diantaranya sebagai kontrasepsi alami saat ibu menyusui dan sebelum menstruasi, menjaga kesehatan ibu dengan mengurangi risiko terkena kanker payudara dan membantu ibu untuk menjalin ikatan batin kepada anak. Pemberian ASI dapat membantu mengurangi pengeluaran keluarga karena tidak membeli susu formula yang harganya mahal(5).

Depkes RI (2011) dalam Septiani (2017) salah satu penyebab rendahnya pemberian ASI di Indonesia adalah kurangnya pengetahuan ibu, sikap ibu, keluarga dan masyarakat akan pentingnya ASI. Masalah ini diperparah dengan gencarnya promosi susu formula dan kurangnya dukungan dari masyarakat, termasuk institusi yang mempekerjakan perempuan yang belum memberikan tempat dan kesempatan bagi ibu menyusui di tempat kerja(6).

Hasil studi pendahuluan yang telah dilakukan oleh peneliti di wilayah kerja Puskesmas Umbulharjo I Yogyakarta pada tanggal 20-24 november 2019 didapatkan data dari kader posyandu bahwa terdapat 32 orang ibu primipara yang berkerja. Berdasarkan hasil wawancara dan observasi yang dilakukan pada $6 \mathrm{ibu}$, diantaranya 4 ibu tidak mengetahui manfaat ASI eksklusif dan teknik menyusui yang benar, sedangkan 2 ibu mengetahui manfaat ASI eksklusif dan belum mengatahui teknik menyusui yang benar. Oleh karena itu peneliti tertarik untuk melakukan penelitian yang berjudul "Hubungan pengetahuan dan sikap ibu tentang ASI eksklusif dengan keberhasilan pemberian ASI eksklusif pada ibu primipara yang bekerja di wilayah kerja Puskesmas Umbulharjo I Yogyakarta".

\section{METODE}

Penelitian ini merupakan penelitian kuantitatif dengan menggunakan rancangan cross sectional. Penelitian ini dilakukan pada februari 2020 di wilayah kerja Puskesmas Umbulharjo I Yogyakarta. Jumlah populasi adalah semua ibu primipara yang bekerja dengan usia balitanya 6-24 bulan berjumlah 32 responden. Teknik pengambilan sampel dengan teknik sampling jenuh. Kriteria inklusi dalam penelitian ini yaitu ibu yang memiliki bayi usia 6-24 bulan, ibu tempat tinggal di wilayah kerja Puskesmas Umbulharjo I Yogyakarta, ibu yang bekerja, ibu yang masih menyusui dan ibu bersedia menjadi responden. Sedangkan kriteria ekslusi pada penelitian ini yaitu bayi memiliki sakit bawaan, misalnya: bibir sumbing dan bayi yang lahir dengan BBLR. Teknik pengumpulan data yang digunakan dalam penelitian ini dengan membagikan tiga kuesioner yaitu Kuesioner pengetahuan, sikap dan keberhasilan pemberian ASI eksklusif. Analisis univariat untuk mengetahui karakteristik responden (umur, pendidikan dan pekerjaan), pengetahuan tentang ASI eksklusif, sikap ibu tentang ASI eksklusif dan keberhasilan pemberian ASI eksklusif. Analisis bivariat menggunakan uji chisquare. Hipotesis dalam penelitian ini Ha: Ada hubungan pengetahuan dan sikap ibu tentang ASI eksklusif dengan keberhasilan pemberian ASI eksklusif pada ibu primipara yang bekerja di wilayah kerja Puskesmas Umbulharjo I Yogyakarta. Sedangkan $\mathrm{H}_{0}$ : Tidak ada hubungan pengetahuan dan sikap ibu tentang ASI eksklusif dengan keberhasilan pemberian ASI eksklusif pada ibu primipara yang bekerja di wilayah kerja Puskesmas Umbulharjo I Yogyakarta. Penelitian dinyatakan layak etik dari Komite Etik Penelitian Kesehatan STIKES Surya Global Yogyakarta dengan nomor 2.10/KEPK/SG/III/2020. Responden yang digunakan dalam penelitian adalah responden yang berpartisipasi dengan sadar dan tanpa paksaan. Sebelum pelaksanaan penelitian, peneliti memberikan penjelasan tentang tujuan, manfaat dan prosepadur penelitian kepada responden. 


\section{HASIL}

\section{Analisis Univariat}

Tabel 1. Karakteristik Responden di Wilayah Kerja Puskesmas Umbulharjo I Yogyakarta

\begin{tabular}{|c|c|c|c|}
\hline \multirow[t]{2}{*}{ No } & \multirow[t]{2}{*}{ Karakteristik Responden } & \multicolumn{2}{|c|}{ Total } \\
\hline & & Frekuensi (f) & Persentase (\%) \\
\hline \multirow[t]{5}{*}{1} & Usia & & \\
\hline & 20-25 tahun & 13 & 40.7 \\
\hline & $26-30$ tahun & 17 & 53.1 \\
\hline & 31-35 tahun & 1 & 3.1 \\
\hline & 36-40 tahun & 1 & 3.1 \\
\hline \multirow[t]{6}{*}{2} & Pendidikan & & \\
\hline & SMP & 1 & 3.1 \\
\hline & SMA & 16 & 50.0 \\
\hline & D3 & 1 & 3.1 \\
\hline & S1 & 13 & 40.7 \\
\hline & S2 & 1 & 3.1 \\
\hline \multirow[t]{3}{*}{3} & Pekerjaan & & \\
\hline & Karyawan swasta & 29 & 90.6 \\
\hline & Guru & 3 & 9.4 \\
\hline \multirow[t]{4}{*}{4} & Pengetahuan & & \\
\hline & Kurang & 10 & 31.2 \\
\hline & Cukup & 9 & 28.1 \\
\hline & Baik & 13 & 40.7 \\
\hline \multirow[t]{4}{*}{5} & Sikap & & \\
\hline & Kurang & 10 & 31,2 \\
\hline & Cukup & 10 & 31,2 \\
\hline & Baik & 12 & 37,6 \\
\hline \multirow[t]{4}{*}{6} & Keberhasilan Pemberian & & \\
\hline & ASI Eksklusif & & \\
\hline & Tidak ASI Eksklusif & 10 & 31.2 \\
\hline & ASI Eksklusif & 22 & 68.8 \\
\hline
\end{tabular}

Berdasarkan Tabel 1 menunjukkan bahwa usia ibu dengan usia 26-30 tahun yaitu 17 orang $(53,1 \%)$, usia $20-25$ tahun yaitu 13 orang (40,6\%), usia 31-35 tahun yaitu 1 orang $(3,1 \%)$ dan usia 36-40 tahun sebanyak $1(3,1 \%)$. Pendidikan ibu dengan pendidikan SMA yaitu 16 orang $(50,0 \%)$, pendidikan S1 yaitu 13 orang $(40,6 \%)$, pendidikan SMP yaitu 1 orang $(3,1 \%)$, pendidikan D3 sebanyak $1(3,1 \%)$ dan pendidikan S2 sebanyak $1(3,1 \%)$. Pekerjaan ibu dengan karyawan swasta yaitu 16 orang $(90,6 \%)$ dan guru yaitu 3 orang $(9,4 \%)$. Pengetahuan ibu dengan pengetahuan baik yaitu 13 orang $(40,7 \%)$, pengetahuan kurang yaitu 10 orang $(31,2 \%)$ dan pengetahuan cukup yaitu 9 orang $(28,1 \%)$. Sikap ibu dengan sikap baik yaitu 12 orang (37,6\%), sikap kurang yaitu 10 orang $(31,2 \%)$ dan sikap cukup yaitu 10 orang $(31,2 \%)$. Ibu memberikan ASI eksklusif yaitu 22 orang $(68,8 \%)$ dan ibu yang tidak ASI eksklusif yaitu 10 orang $(31,2 \%)$. 


\section{Analisis Bivariat}

a. Hubungan Pengetahuan tentang ASI Eksklusif dengan Keberhasilan Pemberian ASI Eksklusif pada Ibu Primipara yang Bekerja di Wilayah Kerja Puskesmas Umbulharjo I Yogyakarta

Tabel 2. Hubungan Pengetahuan Ibu Tentang ASI Eksklusif dengan Keberhasilan Pemberian ASI Eksklusif pada Ibu Primipara Yang Bekerja di Wilayah Kerja Puskesmas Umbulharjo I Yogyakarta

\begin{tabular}{|c|c|c|c|c|c|c|c|}
\hline \multirow{3}{*}{ Pengetahuan } & \multicolumn{4}{|c|}{ ASI Eksklusif } & \multirow{2}{*}{\multicolumn{2}{|c|}{ Jumlah }} & \multirow[t]{3}{*}{ Nilai $p$} \\
\hline & \multicolumn{2}{|l|}{ Tidak } & \multicolumn{2}{|c|}{ Ya } & & & \\
\hline & $\mathbf{n}$ & $\%$ & $\mathbf{N}$ & $\%$ & $\mathbf{n}$ & $\%$ & \\
\hline Kurang & 10 & 31,2 & 0 & 0,0 & 10 & 31,2 & \\
\hline Cukup & 0 & 0,0 & 9 & 28,1 & 9 & 28,1 & $p=0,000$ \\
\hline Baik & 0 & 0,0 & 13 & 40,7 & 13 & 40,7 & \\
\hline Total & 10 & 31,2 & 22 & 68,8 & 32 & 100,0 & \\
\hline
\end{tabular}

Berdasarkan tabel 2 diketahui bahwa 13 responden dengan pengetahuan baik yang memberikan ASI eksklusif sebanyak (40,7\%), 10 responden dengan pengetahuan kurang yang memberikan ASI eksklusif sebanyak (31,2\%), sedangkan 9 responden yang memiliki tingkat pengetahuan cukup yang memberikan ASI eksklusif sebanyak $(28,1 \%)$. Hasil analisis uji statistik dengan menggunakan chi-square diperoleh nilal $\mathrm{p}=0,000$ ( $\mathrm{p}>0,05)$. Hal ini berarti bahwa Ho ditolak dan Ha diterima, yang menunjukan bahwa ada hubungan pengetahuan Ibu tentang ASI eksklusif dengan keberhasilan pemberian ASI eksklusif pada ibu primipara yang bekerja di wilayah kerja Puskesmas Umbulharjo I Yogyakarta.

b. Hubungan Sikap Ibu tentang ASI Eksklusif dengan Keberhasilan Pemberian ASI Eksklusif pada Ibu Primipara yang Bekerja di Wilayah Kerja Puskesmas Umbulharjo I Yogyakarta

Tabel 3. Hubungan Sikap Ibu Tentang ASI Eksklusif dengan Keberhasilan Pemberian ASI Eksklusif pada Ibu Primipara yang Bekerja di Wilayah Kerja Puskesmas Umbulharjo I Yogyakarta

\begin{tabular}{cccccccc}
\hline Sikap & \multicolumn{4}{c}{ ASI Eksklusif } & \multicolumn{2}{c}{ Jumlah } & \multirow{2}{*}{ Nilai $\boldsymbol{p}$} \\
\cline { 2 - 7 } & Tidak & \multicolumn{4}{c}{ Ya } & & \\
\cline { 2 - 7 } & $\mathbf{n}$ & $\mathbf{\%}$ & $\mathbf{N}$ & $\mathbf{\%}$ & $\mathbf{n}$ & $\boldsymbol{\%}$ & \\
\hline Kurang & 10 & 31,2 & 0 & 0,0 & 10 & 31,2 & \\
\hline Cukup & 0 & 0,0 & 10 & 31,2 & 10 & 31,2 \\
\hline Baik & 0 & 0,0 & 12 & 37,6 & 12 & 37,6 \\
\hline Jumlah & 12 & 37,5 & 20 & 62,5 & 32 & 100,0 & \\
\hline
\end{tabular}

Berdasarkan tabel 3 diketahui bahwa 12 responden dengan sikap baik yang memberikan ASI eksklusif sebanyak (37,6\%), 10 responden dengan sikap cukup yang memberikan ASI eksklusif sebanyak (31,2\%), sedangkan 10 responden yang memiliki tingkat pengetahuan kurang yang memberikan ASI eksklusif sebanyak (31,2\%). Hasil analisis uji statistik dengan menggunakan chi-square diperoleh nilai $\mathrm{p}=0,000(\mathrm{p}>0,05)$. Hal ini berarti bahwa Ho ditolak dan Ha diterima, yang menunjukan bahwa ada hubungan sikap Ibu tentang ASI eksklusif dengan keberhasilan pemberian ASI eksklusif pada ibu primipara yang bekerja di wilayah kerja Puskesmas Umbulharjo I Yogyakarta. 


\section{PEMBAHASAN}

Berdasarkan hasil penelitian pada tabel 1 menunjukkan bahwa ibu dengan pengetahuan baik yaitu sebanyak 13 orang (40,7\%), hal ini menunjukkan bahwa pengetahuan ibu tentang ASI eksklusif mayoritas baik. Menurut Rahayu (2010), menyatakan faktor-faktor yang mempengaruhi pengetahuan antara lain: pendidikan, pekerjaan, umur, pengalaman dan kebudayaan(7).

Berdasarkan tabel 1 menunjukkan bahwa mayoritas pendidikan ibu adalah tingkat sarjana (S1) sebanyak 13 responden (40,6\%). Hal ini menunjukkan bahwa pengetahuan ibu mayoritas baik, hal ini tidak lepas dari karakteristik yang dimiliki oleh responden, salah satunya yaitu pendidikan. Pendidikan merupakan usaha sadar dan terencana untuk mewujudkan suasana belajar dan proses pembelajaran agar peserta didik secara aktif dapat mengembangkan potensi dirinya, kepribadian, kecerdasan, akhlak mulia, serta keterampilan yang diperlukan dirinya (Undang-undang Republik Indonesia No. 20 Tahun 2003). Menurut Kurniawati (2014) dalam Yusrina (2016) semakin tinggi tingkat pendidikan seseorang, maka semakin mudah pula seseorang untuk menerima informasi. Informasi yang didapat seseorang nantinya akan mempengaruhi pengetahuan(5).

Berdasarkan tabel 1 menunjukkan bahwa mayoritas pekerjaan ibu sebagai karyawan swasta yaitu sebanyak 16 orang $(90,6 \%)$. Hal ini menunjukkan bahwa pekerjaan ibu dapat mempengaruhi pengetahuan ibu tentang ASI eksklusif dikarenakan lingkungan tempat ibu bekerja tersebut, terpapar tentang ASI eksklusif atau tidak. Dengan begitu meningkat atau tidaknya pengetahuan ibu tersebut tergantung lingkungan tempat ibu bekerja Menurut Rahayu (2010) Lingkungan pekerjaan dapat menjadikan seseorang mendapatkan pengalaman dan pengetahuan, baik secara langsung maupun tidak langsung(7).

Berdasarkan tabel 1 menunjukkan bahwa mayoritas usia ibu sebagai 26-30 tahun yaitu sebanyak 17 orang $(53,1 \%)$. Hal ini menunjukkan bahwa mayoritas usia ibu 20-30 tahun ini menunjukkan sikap berfikir yang sudah matang dan memiliki mental yang diperlukan untuk mempelajari dan menyesuaikan diri pada situasi-situasi yang baru, misalnya mengingat halhal yang dulu pernah dipelajari, penalaran analogi dan berfikir kreatif. Menurut Rahayu (2010) Umur seseorang yang bertambah dapat membuat perubahan pada aspek fisik psikologis, dan kejiwaan. Dalam aspek psikologis taraf berfikir seseorang semakin matang dan dewasa(7).

Hasil penelitian ini sejalan dengan penelitian Yanuarini (2014), tentang hubungan pengetahuan dengan sikap ibu dalam pemberian ASI eksklusif di wilayah kerja Puskesmas Pranggang Kabupaten Kediri. Berdasarkan hasil bahwa sebagian besar umur responden penelitian antara 20-35 tahun (75\%). Tingginya pengetahuan ibu tentang ASI Eksklusif juga dipengaruhi oleh umur, dimana dari segi umur tingkat kematangan dan kekuatan seseorang akan lebih matang dalam perfikir. Hal ini memudahkan ibu dalam menerima informasi karena mereka sudah lebih matang dalam berfikir. Dari informasi tentang ASI Eksklusif, mereka tahu bahwa ASI Eksklusif sangatlah bermanfaat bagi ibu dan bayi(8).

Berdasarkan Tabel 1 menunjukkan bahwa sikap ibu dengan sikap baik yaitu 12 orang (37,6\%), hal ini menunjukkan bahwa sikap responden mayoritas baik. Menurut Nursalam (2003) dalam Wawan dan Dewi (2011) faktor-faktor yang mempengaruhi sikap antara lain: pengalaman pribadi, pengaruh orang lain yang dianggap penting, pengaruh kebudayaan, media massa, lembaga pendidikan dan lembaga agama dan emosional(9).

Hasil penelitian ini sejalan dengan penelitian Wahyuni (2013), tentang hubungan antara pengetahuan dengan sikap ibu primipara mengenai kenyamanan dan teknik yang benar saat menyusui di Klinik Bersalin Mulia Kubu Raya. Sikap ibu primipara mengenai kenyamanan dan teknik yang benar saat menyusui yaitu $43,5 \%$ responden memiliki sikap yang cukup dan $56,5 \%$ responden memiliki sikap yang kurang. Statistik Spearman Rank menunjukan adanya 
hubungan sikap ibu primipara mengenai kenyamanan dan teknik yang benar saat menyusui di Klinik Bersalin Mulia Kubu Raya(10).

Hasil penelitian ini sejalan dengan penelitian Merdhika (2014), tentang pengaruh penyuluhan ASI eksklusif terhadap pengetahuan ibu tentang ASI eksklusif dan sikap ibu menyusui di Kecamatan Kanigoro Kabupaten Blitar. Berdasarkan hasil Analisys of Variance (ANOVA) dapat dikatakan bahwa penyuluhan tentang ASI Eksklusif baik metode buku saku maupun metode simulasi keduanya sama-sama berpengaruh terhadap sikap ibu menyusui dengan Fhitung $=4,053$ lebih besar dari Ftabel $=2,355$. Hasil analisis menggunakan uji $\mathrm{t}$ seperti diatas menunjukkan bahwa terdapat perbedaan sikap ibu menyusui antara ibu yang diberi penyuluhan dengan metode buku saku, ibu yang diberi penyuluhan dengan metode simulasi dan ibu yang diberi penyuluhan tanpa diberi metode apapun dan dapat dikatakan bahwa sikap ibu menyusui yang diberi penyuluhan dengan metode simulasi lebih tinggi daripada ibu yang diberi penyuluhan dengan metode buku saku maupun yang tidak diberi metode. Dari uraian di atas terlihat bahwa penerapan metode simulasi sangat efektif untuk meningkatkan sikap ibu menyusui(11).

Berdasarkan Tabel 1 menunjukkan bahwa ibu memberikan ASI eksklusif yaitu sebanyak 22 orang $(68,8 \%)$, hal ini menunjukkan bahwa responden mayoritas memberikan ASI eksklusif. Menurut Widuri (2013), faktor-faktor yang mempengaruhi pemberian ASI sebagai berikut: pengetahuan, sikap, rasa percaya diri, santai, dukungan keluarga, status gizi yang cukup, mitos-mitos tentang pemberian ASI dan larangan-larangan, breastfeeding selfefficacy, fisik, psikologis(4).

Berdasarkan hasil penelitian pada tabel 1 menunjukkan bahwa ibu dengan pengetahuan baik yaitu sebanyak 13 orang $(40,7 \%)$, hal ini menunjukkan bahwa pengetahuan ibu mayoritas baik. Pengetahuan adalah hasil penginderaan manusia, atau hasil tahu seseorang terhadap objek melalui indera yang dimilikinya (mata, hidung, telinga dan sebagainya). Dengan sendirinya pada waktu penginderaan sampai menghasilkan pengetahuan tersebut sangat dipengaruhi oleh intensitas perhatian dan persepsi terhadap objek. Sebagian besar pengetahuan seseorang diperoleh melalui indera penglihatan dan indera pendengaran. Pengetahuan seseorang terhadap objek mempunyai intensitas atau tingkat yang berbedabeda(12).

Hasil penelitian ini sejalan dengan penelitian Nurleli (2017), tentang hubungan pengetahuan dan sikap ibu dengan tindakan pemberian ASI eksklusif di Puskesmas Rambung Kecamatan Binjai Selatan Kota Binjai. Hasil penelitian ini menunjukkan hasil uji chi-square memperlihatkan bahwa pada table contingency $2 \times 2$, tidak ada yang memiliki nilai harapan (expected value E) kurang dari 5, sehingga nilai p-value yang dipergunakan adalah nilai contingency correction $t$-count $=32.302$ dengan $\mathrm{p}$ value $-0,000$, lebih kecil dari 0,05 , sehingga dapat disimpulkan bahwa pengetahuan memiliki hubungan signifikan dengan tindakan pemberian ASI eksklusif(13).

Berdasarkan tabel 2 diketahui bahwa 13 responden dengan pengetahuan baik yang memberikan ASI eksklusif sebanyak (40,7\%). Hasil analisis uji statistik dengan menggunakan chi-square diperoleh nilai $\mathrm{p}=0,000(\mathrm{p}>0,05)$. Hal ini berarti bahwa Ho ditolak dan $\mathrm{Ha}$ diterima, yang menunjukan bahwa ada hubungan pengetahuan ibu tentang ASI eksklusif dengan keberhasilan pemberian ASI eksklusif pada ibu primipara yang bekerja di wilayah kerja Puskesmas Umbulharjo I Yogyakarta.

Hasil penelitian ini sejalan dengan penelitian yang dilakukan oleh Septiani (2017), tentang faktor-faktor yang berhubungan dengan pemberian ASI eksklusif oleh ibu menyusui yang bekerja sebagai tenaga kesehatan. Hasil penelitian ini disebutkan bahwa pemberian ASI eksklusif lebih banyak pada kelompok ibu dengan pengetahuan baik $(72,8 \%)$ dibandingkan ibu dengan pengetahuan kurang (20,6\%). Hasil uji statistik diperoleh nilai $\mathrm{p}$ value $=0,001$, 
sehingga dapat disimpulkan bahwa ada hubungan yang signifikan antara pengetahuan dengan pemberian ASI eksklusif(6).

Berdasarkan tabel 3 diketahui bahwa 12 responden dengan sikap baik yang memberikan ASI eksklusif sebanyak (37,6\%). Hasil analisis uji statistik dengan menggunakan chi-square diperoleh nilai $\mathrm{p}=0,000$ ( $\mathrm{p}>0,05)$. Hal ini berarti bahwa Ho ditolak dan Ha diterima, yang menunjukan bahwa ada hubungan sikap Ibu tentang ASI eksklusif dengan keberhasilan pemberian ASI eksklusif pada ibu primipara yang bekerja di wilayah kerja Puskesmas Umbulharjo I Yogyakarta.

Hasil penelitian ini sejalan dengan penelitian yang dilakukan oleh Septiani (2017), tentang faktor-faktor yang berhubungan dengan pemberian ASI eksklusif oleh ibu menyusui yang bekerja sebagai tenaga kesehatan. Hasil penelitian ini disebutkan bahwa pemberian ASI eksklusif lebih banyak pada kelompok responden yang memiliki sikap positif $(72,1 \%)$ dibandingkan yang memiliki sikap negatif $(40,7 \%)$. Hasil uji statistik diperoleh nilai p value= 0,001, sehingga dapat disimpulkan bahwa ada hubungan yang signifikan antara sikap dengan pemberian ASI eksklusif. Hasil analisis juga menunjukkan nilai OR sebesar 3.7, artinya bahwa responden yang memiliki sikap positif terhadap pemberian ASI memiliki peluang 3.7 kali lebih besar untuk memberikan ASI eksklusif dibandingkan dengan responden yang memiliki sikap negatif terhadap ASI(6). Pada penelitian tidak dilakukan uji nilai OR sehingga penelitian ini tidak mengetahui seberapa besar peluang sikap positif dibandingkan dengan sikap negatif untuk keberhasilan pemberian ASI eksklusif

\section{SIMPULAN}

Berdasarkan hasil penelitian dan yang telah dilakukan terdapat hubungan pengetahuan ibu tentang ASI eksklusif dengan keberhasilan pemberian ASI eksklusif pada ibu primipara dan terdapat hubungan sikap ibu tentang ASI eksklusif dengan keberhasilan pemberian ASI eksklusif pada ibu primipara yang bekerja di wilayah kerja Puskesmas Umbulharjo I Yogyakarta.

\section{SARAN}

Bagi ibu yang menyusui di wilayah kerja Puskesmas Umbulharjo I Yogyakarta dapat mamberikan gambaran bagi ibu yang menyusui serta menambah informasi, pengetahuan dan wawasan tentang pentingnya pemberian ASI eksklusif sehingga ibu tidak hanya sekedar tahu tetapi juga sadar dalam memberikan ASI pada bayinya.

\section{UCAPAN TERIMA KASIH}

Penulis mengucapkan terimakasih kepada Puskesmas Umbulharjo 1 dan kader posyandu, yang telah memfasilitasi dan membantu pengumpulan data sehingga berjalan dengan lancar dan tak lupa ucapan terimakasih kepada pihak review artikel JKP yang ikut membantu dalam kelayakan.

\section{DAFTAR PUSTAKA}

1. Ramos JN. Kesehatan Ibu dan Bayi Baru Lahir. Jakarta: Penerbit Erlangga; 2017.

2. Kesehatan D. Provinsi Di Yogyakarta Tahun 2017. Profil Kesehat Provinsi Yogyakarta. 2017;38-9.

3. Kemenkes. info DATIN (Pusat Data dan Informasi Kementrian RI). Kementeri Kesehat RI. 2018;1-7.

4. Widuri H. Cara Mengelola ASI Eksklusif Bagi Ibu Bekerja. Yogyakarta: Gosyen Publishing; 2013.

5. Yusrina A, Devy SR. Influencing Factors of the Intentions Mothers Breastfeeding 
Exclusively in Kelurahan Magersari, Sidoarjo. J Promkes. 2016;4(1):11-21.

6. Septiani H, Budi A, Karbito. Faktor-Faktor yang Berhubungan dengan Pemberian ASI Eksklusif Oleh Ibu Menyusui yang Bekerja Sebagai Tenaga Kesehatan. J Aisyah J Ilmu Kesehatan 2 (2), $159-174$ [Internet]. 2017; Available from: https://www.neliti.com/publication/217373/faktor-faktor-yang-berhubungan-denganpemberian-ASI-eksklusif-oleh-ibu-menyusui

7. Rahayu, Kurnia, Siti. Perpajakan Indonesia "Konsep dan Aspek Formal". Yogyakarta: Graha Ilmu; 2010.

8. Yanuarini TA, Rahayu DE, Prahitasari E. Hubungan Pengetahuan Dengan Sikap Ibu dalam Pemberian ASI Eksklusif di Wilayah Kerja Puskesmas Pranggang Kabupaten Kediri. J Ilmu Kesehat. 2017;3(1):1.

9. Wawan A, Dewi M. Teori \& Pengukuran Pengetahuan, Sikap dan Perilaku Manusia. Yogyakarta: Nuha Medika; 2011.

10. Wahyuni S, Ligita T, Winarianti. Hubungan antara Pengetahuan dengan SIkap Ibu Primipara mengenai Kenyamanan dan Teknik yang Benar saat Menyusui di KLinik Bersalin Mulia Kubu Raya. 2013;

11. Merdhika WAR, Mardji, Devi M. Pengaruh Penyuluhan ASI Eksklusif terhadap Pengetahuan Ibu tentang ASI Eksklusif dan Sikap Ibu Menyusui di Kecamatan Kanigoro Kabupaten Blitar. Teknol Dan Kejuru. 2014;37(1):65-72.

12. Notoadmodjo S. Promosi Kesehatan dan Ilmu Perilaku. Jakarta: Rineka Cipta; 2010.

13. Nurleli N, Purba JM, Sembiring R. Hubungan Pengetahuan Dan Sikap Ibu Dengan Tindakan Pemberian Asi Eksklusif Di Puskesmas Rambung Kecamatan Binjai Selatan Kota Binjai Tahun 2017. J Ris Hesti Medan Akper Kesdam I/BB Medan. 2018;3(1):1. 